Article

\title{
Effects of Plant-Soil Feedback on Switchgrass Productivity Related to Microbial Origin
}

\author{
James R. Kiniry ${ }^{1, *}$, Caroline E. Arthur ${ }^{2}$, Katherine M. Banick ${ }^{1}$, Felix B. Fritschi ${ }^{3}$, Yanqi $\mathrm{Wu}^{4}{ }^{4}$ and \\ Christine V. Hawkes $2,5, * \mathbb{D}$ \\ 1 USDA-ARS, Grassland Soil and Water Research Laboratory, 808 East Blackland Road, Temple, \\ TX 76502, USA; katherinebanick@gmail.com \\ 2 Department of Integrative Biology, University of Texas, Austin, TX 78712, USA; carolinearthur11@gmail.com \\ 3 Division of Plant Sciences, University of Missouri, Columbia, MO 65211, USA; FritschiF@missouri.edu \\ 4 Department of Plant and Soil Sciences, Oklahoma State University, Stillwater, OK 74708, USA; \\ yanqi.wu@okstate.edu \\ 5 Department of Plant and Microbial Biology, North Carolina State University, Raleigh, NC 27607, USA \\ * Correspondence: jim.kiniry@usda.gov (J.R.K.); chawkes@ncsu.edu (C.V.H.)
}

Received: 27 October 2020; Accepted: 24 November 2020; Published: 26 November 2020

\begin{abstract}
A great deal of effort has been applied to maximizing switchgrass (Panicum virgatum L.) production for bioenergy by leveraging existing local adaptation to climate and via nutrient management in this perennial grass crop. However, the biotic component of soils can also affect plant production and long-term suitability at a given site. Here, we tested how productivity of four switchgrass cultivars were affected by four microbial sources from the Great Plains. All inoculum soil sources were previously conditioned by a mixture of switchgrass cultivars, allowing us to explicitly address plant-soil feedback effects. Microbial soil inocula were added to a consistent background soil to avoid physicochemical variation across the sources. We found that the soil microbial inoculum source mattered more than cultivar in determining switchgrass biomass. The addition of microbes resulted in smaller plants, with the largest plants found on control soils with no inoculum, but some inocula were less negative than others. There was no geographic matching between cultivars and soil microbial inoculum, suggesting little local adaptation to the biotic component of soils. In addition, measurements of fungal root colonization suggest that fungi are not responsible for the observed patterns. Based on these results, we suggest that switchgrass cultivation could benefit from considering effects of the soil biota. Additional work is needed to generalize these patterns over time, to a wider geographic area, and to a broader range of cultivars.
\end{abstract}

Keywords: Panicum virgatum; bioenergy; perennial crop; geographic variation

\section{Introduction}

Productivity of plants, including of perennial grasses such as switchgrass (Panicum virgatum L.), is known to vary regionally [1-6]. Switchgrass is one of the primary plant species of interest for bioenergy production in the USA. It has repeatedly shown promise as a highly productive perennial grass adapted to marginal and prime agricultural soils. Switchgrass has high variation in ecotypes, growing as far south as northern Mexico and as far north as southern Canada.

Farmers and ranchers have long known that abiotic soil differences are a primary determinants of perennial grass productivity (e.g., [4,7]). However, effects of the biotic component of soil remain poorly understood. Most grasses in natural ecosystems are negatively affected by plant-soil feedback $[8,9]$, in which soil microbial communities cultivated by plants can then subsequently alter plant productivity 
and fitness. Far less is known about plant-soil feedback in agricultural ecosystems beyond pathogen and herbivore accumulation [10], despite its potential to help optimize planting and rotation practices [11].

Studies of plant-soil feedback have primarily considered variation among species, although intraspecific feedback is likely to be important for the maintenance of genetic diversity and its effects on community and ecosystem processes [12]. Recently, intraspecific variation was observed in switchgrass plant-soil feedback from soils with different rainfall histories [13]. Intraspecific variation in plant-soil feedback may be more likely for perennial crops with genotypes that exhibit large differences in traits, such as productivity, rooting depth, pathogen susceptibility, and mycorrhizal dependency [14,15]. Extensive morphological variation among switchgrass cultivars supports the potential for intraspecific variation in plant-soil feedback, which may affect the choice of the kind of cultivars that are planted in what regions in the future.

Regional variation in plant-soil feedback may also be caused by local adaptation [16]. Plant species generally experience more negative feedback in their local, "home" soils compared to novel, "away" soils [17]. This expectation is largely due to the buildup of detrimental pathogen interactions in home soils where conspecifics have been grown and escape from those pathogens in away soils [18-20]. However, it is also possible that local or regional adaptation to beneficial microorganisms could lead to more positive feedback in home versus away soils. For example, ecotypes of the perennial grass, Andropogon gerardii, benefitted most from local mycorrhizal fungi that were able to alleviate nutrient limitations in their home soils [21]. Therefore, we posit that soil from various regions could be, via plant effects on development of the microbial community, important contributors to regional adaptation and production of various switchgrass ecotypes.

Therefore, our objective was to investigate how growth of different switchgrass cultivars originating in the Great Plains was affected by feedback from soils collected from switchgrass stands across the same region. We used four cultivars representing lowland and upland ecotypes that are known to exhibit regional variation in productivity and related traits [1-6]. To separate soil effects from microbial effects, we grew the cultivars in a single sterilized background soil, inoculated with a small amount of live soil from four sites from Texas to Missouri. Prior to soil collection at each site, the field plots were previously grown with the same mixtures of switchgrass cultivars [4].

We hypothesized that most feedback would be negative given previous results of meta-analyses on soil feedback to grasses [8,22], but we expected overall less negative feedback for the more vigorous lowland compared to upland ecotypes. However, based on 3.5-7.9 $\times$ regional yield variation of the selected cultivars [4], we predicted that soil feedback would outweigh cultivar or ecotype variation as non-microbial soil properties were held constant. We further expected to find an interaction of cultivar and soil inoculum source created by regional home versus away effects. Finally, we also examined root-associated fungi at harvest because these are often implicated in plant-soil feedback, with the expected benefits from plant cultivation of mycorrhizal fungi, and reduced growth from a buildup of fungal pathogens.

\section{Materials and Methods}

This study was conducted in a greenhouse at the USDA-ARS Grasslands, Soil and Water Research Station in Temple, TX, USA. The greenhouse was maintained at $22.2{ }^{\circ} \mathrm{C}$ and automatic irrigation by overhead spray was applied daily to prevent any drought stress throughout the experiment. Average photosynthetically active radiation levels in the greenhouse were $61 \%$ of outside values. We used $1.9 \mathrm{~L}$ round, plastic, single-layer pots, which were adequate for determining responsiveness for these young plants. To avoid nutrient differences created by different soils, we used a single background soil comprised of a 1:1 v:v sterilized mixture of local Houston Black Clay soil and quartz sand. Soil and sand were sterilized by autoclaving three times with $24 \mathrm{~h}$ rest in between. No fertilizer was applied to the pots. While soil nutrient levels were not measured, plants showed no signs of nutrient deficiency.

To test potential for soil feedbacks, live soils were collected in May 2014 from four switchgrass stands in Temple, TX, USA; Stillwater, OK, USA; Mt. Vernon, MO, USA; and Columbia, MO, USA, 
which had previously been conditioned by a mixture of switchgrass cultivars that were established in 2009 and were known to differ in soil properties (Table 1, [4]). At each site, soils were collected as a grab sample of $\sim 1 \mathrm{~kg}$ from each of four locations within the plots, to a depth of $15 \mathrm{~cm}$. Soils were then combined and homogenized by sieving to $2 \mathrm{~mm}$. Sieved soils were used as inocula by mixing $10 \%$ of the live soil into the background pot soil by volume $(\sim 190 \mathrm{~mL})$. Live soils were added just prior to seed addition in May 2014. Control pots were included with no live inoculum, but an equal volume of sterile background soil. Pots were filled to $2.5 \mathrm{~cm}$ below the top and placed $\sim 15 \mathrm{~cm}$ apart on the bench to limit cross-contamination.

Table 1. Locations and characteristics of soils used for inocula.

\begin{tabular}{|c|c|c|c|c|c|c|c|}
\hline Source Location & Soil Series & Soil Taxonomic Class & $\begin{array}{c}\text { Soil } \\
\text { Texture }\end{array}$ & Latitude & $\mathrm{pH}$ & $\begin{array}{r}\text { Organic } \\
\text { Matter \% }\end{array}$ & $\begin{array}{l}\text { Cation Exchange } \\
\text { Capacity (mEq } \\
\text { per } 100 \mathrm{~g} \text { Soil) }\end{array}$ \\
\hline Temple, TX, USA & Houston & Udic Haplusterts & black clay & 31.04 & 7.9 & 2.38 & 45.9 \\
\hline Mt. Vernon, MO, USA & Gerald & Aeric Fragiaqualfs & silt loam & 37.07 & 5.9 & 1.70 & 10.2 \\
\hline Columbia, MO, USA & Mexico & Vertic Epiaqualfs & silt loam & 38.89 & 6.3 & 1.67 & 16.3 \\
\hline
\end{tabular}

To test how switchgrass plant-soil feedback varied across these regional soils, we focused on four cultivars that also originated in the Great Plains. We selected two lowland ecotype cultivars, Alamo and Kanlow, and two upland ecotype cultivars, Blackwell and Cave-In-Rock (Table 2). Compared to upland ecotypes, lowland ecotypes are usually more productive with taller, thicker tillers and larger leaves, more cellulose and lower nitrogen in dry matter, and delayed reproduction [23-26]. The specific cultivars selected are also known to vary in both aboveground biomass production (Table 2) and other traits, such as maximum leaf area index and water use efficiency [4]. Seeds of each cultivar were overplanted and thinned to one plant per pot after seedling emergence. The full design included 5 soil inocula ( 4 live and 1 control $) \times 4$ cultivars $\times 5$ replicates $=100$ pots. All pots were randomly positioned on benches in the greenhouse.

Table 2. Switchgrass cultivars data from Kiniry et al. (2013). Previous field yields are from the third growing season.

\begin{tabular}{|c|c|c|c|c|c|c|c|}
\hline \multirow[b]{2}{*}{ Cultivar } & \multirow[b]{2}{*}{$\begin{array}{c}\text { State of } \\
\text { Origin }\end{array}$} & \multirow[b]{2}{*}{$\begin{array}{l}\text { Latitude } \\
\text { of Origin }\end{array}$} & \multirow[b]{2}{*}{ Ecotype } & \multicolumn{4}{|c|}{ Previous Field Yields $\left(\mathrm{Mg} \mathrm{ha}^{-1} \pm 1 \mathrm{SD}\right)$} \\
\hline & & & & $\begin{array}{c}\text { Temple, } \\
\text { TX, USA }\end{array}$ & $\begin{array}{l}\text { Stillwater, } \\
\text { OK, USA }\end{array}$ & $\begin{array}{l}\text { Mt. Vernon, } \\
\text { MO, USA }\end{array}$ & $\begin{array}{l}\text { Columbia, } \\
\text { MO, USA }\end{array}$ \\
\hline Alamo & Texas & 28 & Lowland & $30.6 \pm 26.5$ & $15.0 \pm 7.0$ & $15.1 \pm 7.0$ & $20.9 \pm 8.9$ \\
\hline Kanlow & Oklahoma & 35 & Lowland & $13.8 \pm 7.3$ & $12.4 \pm 0.9$ & $21.2 \pm 9.7$ & $21.2 \pm 7.0$ \\
\hline Blackwell & Oklahoma & 37 & Upland & $4.8 \pm 2.8$ & $8.8 \pm 3.6$ & $11.6 \pm 1.9$ & $6.7 \pm 1.4$ \\
\hline Cave-In-Rock & Illinois & 38 & Upland & $4.8 \pm 1.5$ & $12.5 \pm 3.6$ & $14.8 \pm 3.5$ & $8.9 \pm 1.3$ \\
\hline
\end{tabular}

Given that switchgrass is a perennial, we ran the experiment for two growing seasons based on previous data showing that switchgrass plant-soil feedbacks strengthened in the second growing season [27]. The above-ground biomass was removed from all pots at the end of the 2014 growing season. Plant height and tiller number were measured every 4-5 weeks from April to July 2015. In July 2015, plants were destructively harvested. Shoots were cut and dried to constant weight in a forced air drying oven. Roots were washed free of soil, weighed fresh, and a subset of $\sim 0.5 \mathrm{~g}$ fresh roots $<2 \mathrm{~mm}$ in diameter of known weight was removed to assay for root colonization by fungi. The remainder of each root sample was dried, together with the shoot samples, and used to determine total root dry matter per plant. The samples for fungal colonization were stored in ethanol prior to clearing in $\mathrm{KOH}$ and staining with acid fuchsin [28]. Septate hyphae, aseptate hyphae, arbuscules, and vesicles were counted using the line-intercept method at 160× with 100 intersections per sample [29]. Septate hyphae were interpreted as non-mycorrhizal, while aseptate hyphae, arbuscules, and vesicles were considered mycorrhizal structures. 
Plant-soil feedback was calculated on total plant biomass as $\ln$ (treatment/control) for symmetric values around zero following Pernilla-Brinkmann et al. [30]. Plant biomass, feedback, and root colonization by septate hyphae, aseptate hyphae, arbuscules, and vesicles were analyzed with ANOVA as a function of cultivar, soil source, and their interactions, with both treatments as fixed effects. Plant height was analyzed similarly, but using a repeated measures ANOVA to account for multiple measurements over time and Greenhouse-Geisser corrections when sphericity was violated. For significant effects, posthocs were performed with Ryan-Einot-Gabriel-Welsh $F$ tests. Planned contrasts were used to ask how biomass and feedback of each cultivar was compared between home and away soil inocula sources, with home defined as the regional soil source nearest to the cultivar origin (Tables 1 and 2). Biomass data were $\ln$ transformed and root colonization data were arcsine-square root transformed for normality and homogeneity of variance. Transformed data are presented as back-transformed values with asymmetric 95\% confidence intervals. To correct for multiple comparisons, we used a Bonferroni-corrected $\alpha=0.006$. All statistics were carried out in SPSS v. 26 (IBM, Armonk, NY, USA).

\section{Results}

\subsection{Growth over Time}

Switchgrass cultivars differed in their overall growth forms (Table 3). Alamo was $140 \%$ taller, but had up to $20 \%$ fewer tillers compared to the average of other cultivars. Blackwell was up to $21 \%$ shorter than other cultivars, but had $130 \%$ more tillers on average. Kanlow and Cave-In-Rock were consistently intermediate in both average height and tiller number. With the exception of Kanlow, cultivars in control soils were generally of intermediate height, but had $124-200 \%$ more tillers than in live-inoculated soils. However, tiller number depended on the interaction of cultivar and soil, and no single soil inoculum source was consistently best. There was also variation in cultivar height over time based on soil inoculum source (Table 3). For example, Alamo inoculated with soils from Stillwater increased in height by only $\sim 8 \mathrm{~cm}$ from April to July, whereas Alamo inoculated with soils from Mt. Vernon or Columbia grew by $\sim 60 \mathrm{~cm}$ during the same time period (Figure 1).

Table 3. Repeated measures ANOVAs for height and tillers as a function of cultivar ("Cultivar"), soil inoculum source ("Soil"), and date of measurement ("Date"). Greenhouse-Geisser corrected $p$ values are reported for within-subjects effects (height, epsilon $=0.630$; tillers, epsilon $=0.666$ ).

\begin{tabular}{cccccccc}
\hline & & \multicolumn{3}{c}{ Height } & \multicolumn{3}{c}{ Tillers } \\
& df & MS & $\boldsymbol{F}$ & $\boldsymbol{p}$ & MS & $\boldsymbol{F}$ & $\boldsymbol{p}$ \\
\hline Between-subjects & & & & & & & \\
Cultivar & 3 & 10447.75 & 14.57 & $<0.001$ & 3173.17 & 11.78 & $<0.001$ \\
$\quad$ Soil & 4 & 3745.74 & 5.22 & 0.001 & 2596.87 & 9.64 & $<0.001$ \\
Cultivar $\times$ Soil & 12 & 1331.51 & 1.86 & 0.055 & 994.60 & 3.69 & $<0.001$ \\
$\quad$ Error & 71 & 717.01 & & & 269.27 & & \\
Within-Subjects & & & & & & & \\
$\quad$ Date & 4 & 7805.84 & 107.36 & $<0.001$ & 1205.94 & 30.20 & $<0.001$ \\
Date $\times$ Cultivar & 12 & 178.01 & 2.45 & 0.029 & 86.47 & 2.17 & 0.032 \\
Date $\times$ Soil & 16 & 94.63 & 1.30 & 0.195 & 53.69 & 1.34 & 0.205 \\
Date $\times$ Cultivar $\times$ Soil & 48 & 187.94 & 2.59 & $<0.001$ & 51.86 & 1.30 & 0.145 \\
$\quad$ Error & 71 & 72.71 & & & 39.93 & & \\
\hline
\end{tabular}




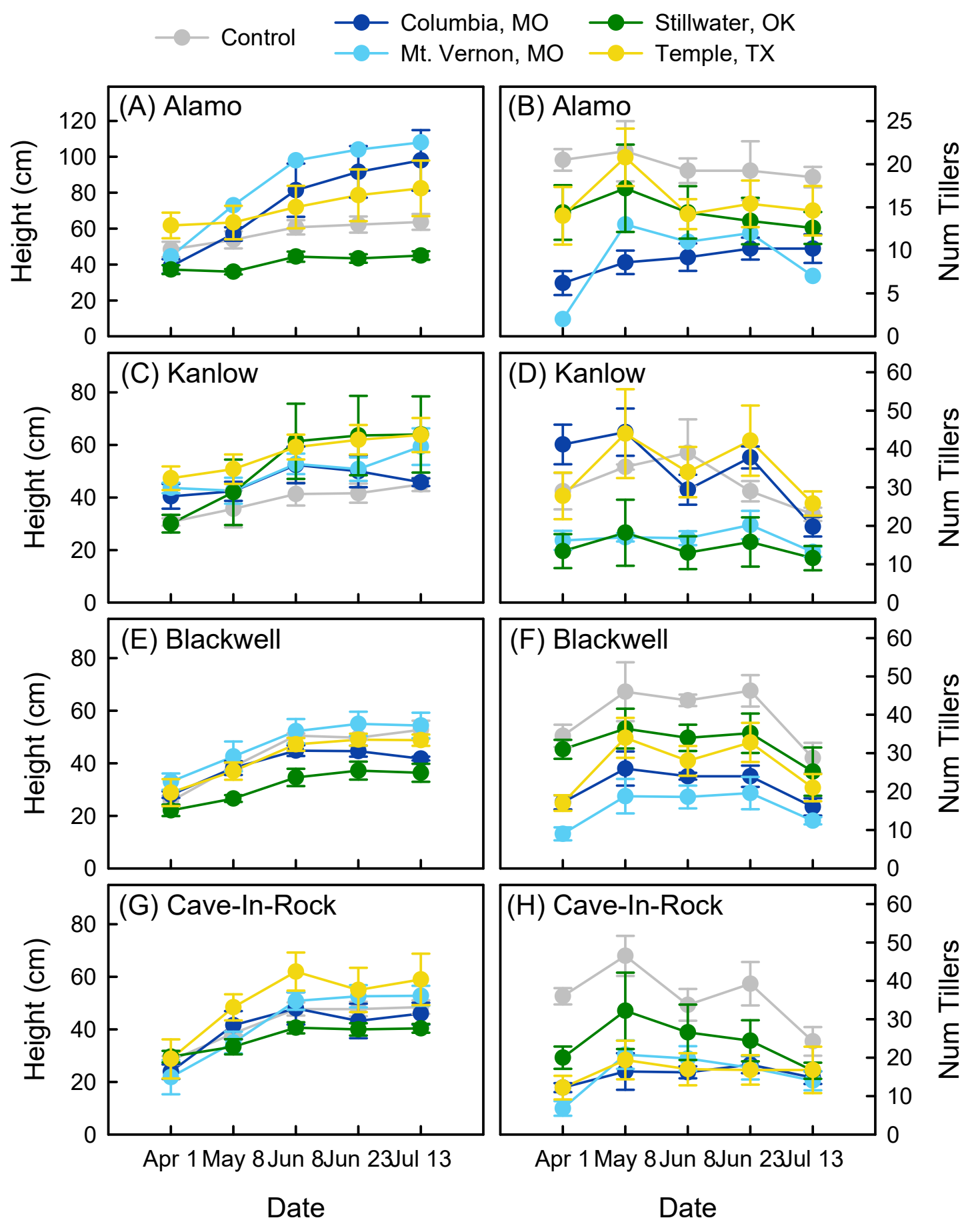

Figure 1. Height (left) and number of tillers (right) for switchgrass cultivars (A-H) and soil inoculum sources (colors) across five dates from April to July 2015. Note the different scales for Alamo (A,B) compared to all other ecotypes $(\mathbf{C}-\mathbf{H})$. Points are means \pm SE $(n=4-5)$.

\subsection{Biomass and Feedback at Harvest}

More switchgrass biomass was in roots than in shoots (Figure 2), but there was no differences in total plant biomass among switchgrass cultivars (Table 4 ). In contrast, feedback was $2 \times$ more negative for the upland ecotypes, Blackwell and Cave-In-Rock, compared to the lowland ecotypes, Alamo and Kanlow (Figure 2). Soil inoculum source affected total plant biomass (Table 4), with the largest plants in control soils (Figure 2). Plants were also 1.55× larger when grown with soil inoculum from Temple and Columbia compared to Stillwater and Mt. Vernon. Soil inoculum effects on feedback were parallel 
to biomass, with more negative feedback observed for the soil inocula that supported smaller plants (Figure 2). There were no interactions of cultivar and soil inoculum source on either biomass or feedback. Based on the planned comparisons, cultivars did not differ in biomass or feedback in home vs. away soil inocula.
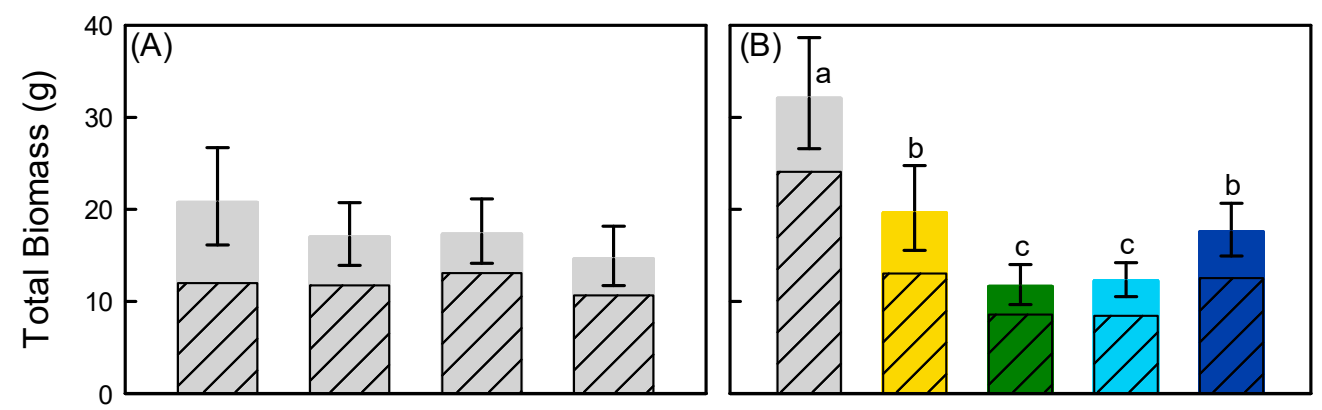

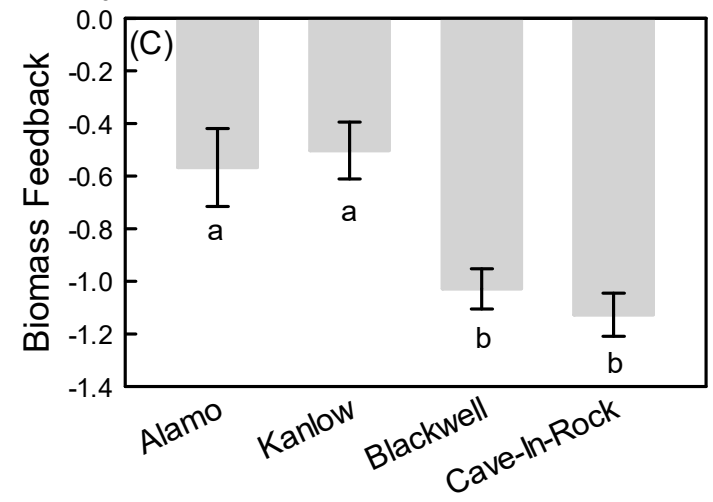

Switchgrass Cultivar

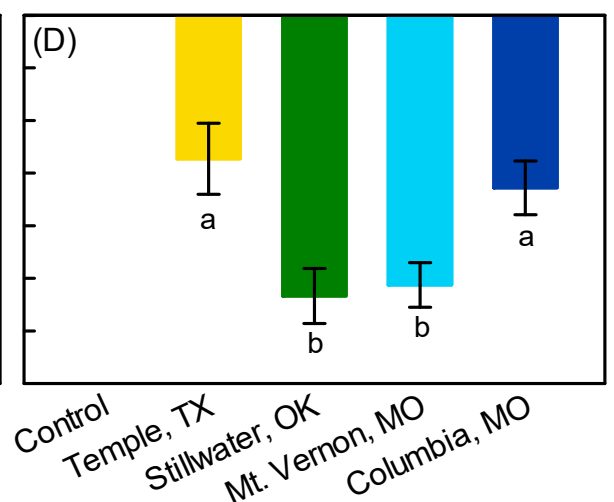

Soil Inoculum Source

Figure 2. Total biomass (A,B) and biomass feedback $(\mathbf{C}, \mathbf{D})$ as a function of switchgrass cultivar $(\mathbf{A}, \mathbf{C})$ and soil inoculum source $(\mathbf{B}, \mathbf{D})$. Hatches show the portion of total biomass in roots. Bars are means $\pm 95 \%$ CI (biomass) or 1 SE (feedback) with $n=22-24$ for cultivar and $n=17-20$ for soil inoculum source. Letters indicate significant differences in posthoc comparisons.

Table 4. ANOVAs for biomass and biomass feedback as a function of plant cultivar, soil inoculum source, and their interaction.

\begin{tabular}{cccccccccc}
\hline & \multicolumn{4}{c}{ Biomass } & \multicolumn{5}{c}{ Feedback } \\
\hline Treatment & df & MS & $\boldsymbol{F}$ & $\boldsymbol{p}$ & $\mathbf{d f}$ & MS & $\boldsymbol{F}$ & $\boldsymbol{p}$ \\
\hline Cultivar & 3 & 0.244 & 1.594 & 0.198 & 3 & 1.760 & 11.417 & $<0.001$ \\
Soil & 4 & 2.910 & 19.023 & $<0.001$ & 3 & 1.271 & 8.246 & $<0.001$ \\
Cultivar $\times$ soil & 12 & 0.265 & 1.729 & 0.078 & 9 & 0.234 & 1.515 & 0.163 \\
Error & 74 & 0.153 & & & 61 & 0.154 & & \\
\hline
\end{tabular}

\subsection{Root Colonization at Harvest}

Root colonization rates were low overall, with an average of $13 \%$ aseptate hyphae, $4 \%$ septate hyphae, $1 \%$ arbuscules, and $7 \%$ vesicles across all treatments. Switchgrass cultivars differed in fungal root colonization (Table 5, Figure 3). Kanlow roots had the fewest fungal structures overall. Septate and aseptate hyphae were 4-7 times more abundant in Alamo roots on average compared to other cultivars. Arbuscules were overall 10 times more abundant in Alamo and Cave-In-Rock compared to Blackwell and Kanlow, but this was largely due to the pattern in control soils. In soils with live inocula, Alamo had the most arbuscules in soil inocula from Columbia and Cave-In-Rock had the fewest arbuscules in soil inocula from Mt. Vernon compared to all other cultivars. There were no differences in arbuscules among cultivars when inoculated with soils from Stillwater or Temple. Vesicles were 
10 times less abundant in Kanlow roots compared to all other cultivars. Soil inoculum source had no effect on root colonization, except roots in control soils had fewer vesicles than those in inoculated soils.

Table 5. ANOVAs for fungal root colonization (septate hyphae, aseptate hyphae, arbuscules, vesicles) as a function of plant cultivar, soil inoculum source, and their interaction.

\begin{tabular}{|c|c|c|c|c|c|c|c|c|c|c|c|c|c|}
\hline & & \multicolumn{3}{|c|}{ Septate Hyphae } & \multicolumn{3}{|c|}{ Aseptate Hyphae } & \multicolumn{3}{|c|}{ Arbuscules } & \multicolumn{3}{|c|}{ Vesicles } \\
\hline & df & MS & $F$ & $p$ & MS & $F$ & $p$ & MS & $F$ & $p$ & MS & $F$ & $p$ \\
\hline Cultivar & 3 & 0.198 & 14.327 & $<0.001$ & 0.488 & 14.473 & $<0.001$ & 0.050 & 12.508 & $<0.001$ & 0.21 & 17.990 & $<0.001$ \\
\hline Soil & 4 & 0.048 & 3.486 & 0.012 & 0.110 & 3.253 & 0.016 & 0.001 & 0.319 & 0.864 & 0.17 & 14.531 & $<0.001$ \\
\hline $\begin{array}{c}\text { Cultivar } \\
\times \text { Soil }\end{array}$ & 12 & 0.028 & 2.020 & 0.034 & 0.053 & 1.570 & 0.119 & 0.013 & 3.142 & 0.001 & 0.029 & 2.497 & 0.008 \\
\hline Error & 74 & 0.014 & & & 0.034 & & & 0.004 & & & 0.012 & & \\
\hline
\end{tabular}

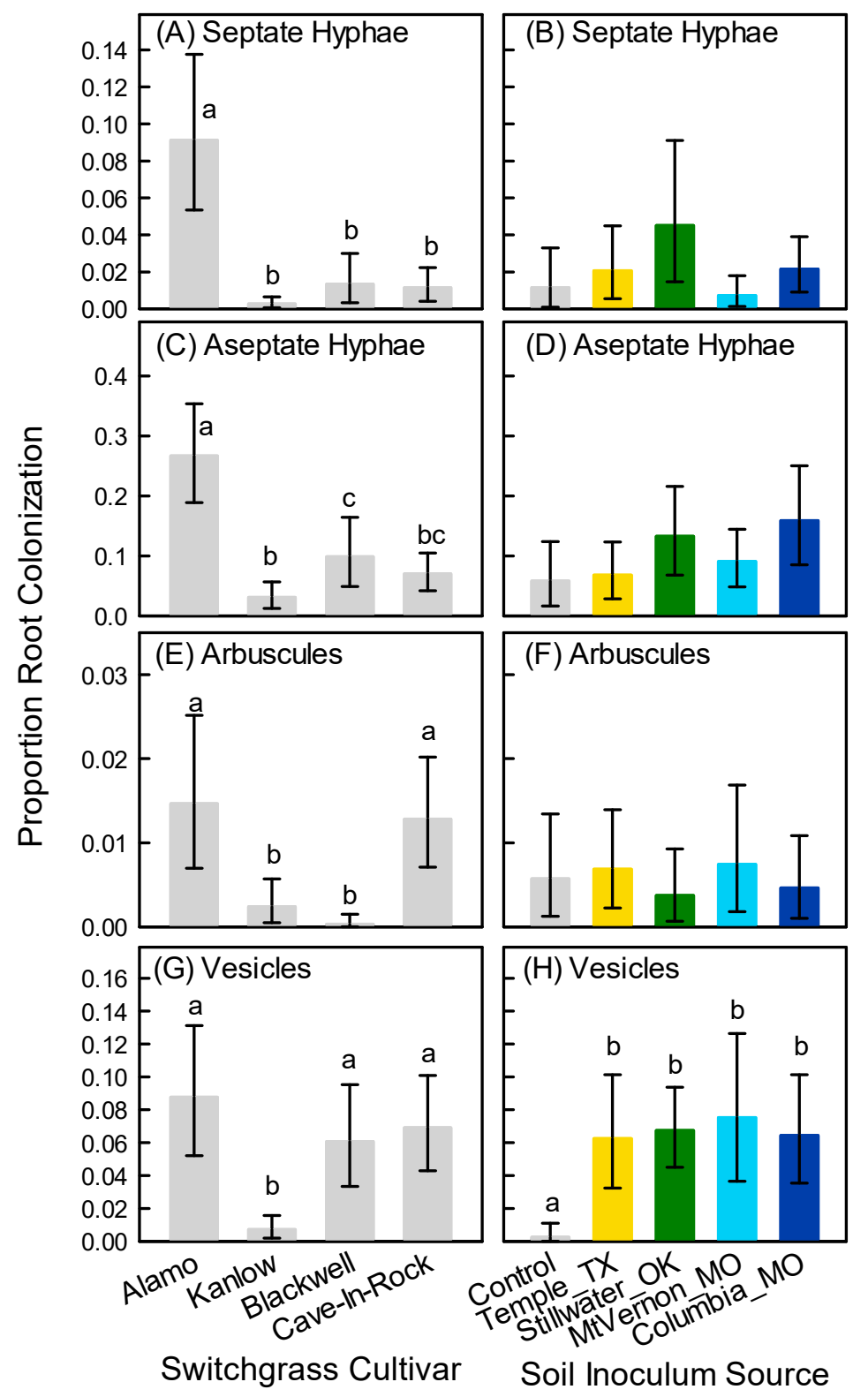

Figure 3. Root colonization by septate hyphae (A,B), aseptate hyphae (C,D), arbuscules (E,F), and vesicles $(\mathbf{G}, \mathbf{H})$ as a function of switchgrass cultivar (left) and soil inoculum source (right). Bars are means $\pm 95 \%$ CI (cultivar $n=22-24$; soil source $n=17-20$ ). Letters indicate significant differences in posthoc comparisons. 


\section{Discussion}

As expected, plant-soil feedback was generally negative, with a lower biomass in all soils treated with live inocula from field-grown switchgrass stands compared to control soils. Feedback was less negative for lowland compared to upland ecotypes, but this was not reflected in switchgrass biomass. Instead, both feedback and biomass largely tracked the soil treatments. In addition, height and tiller growth depended on the interaction of cultivar and soil inoculum source. These results suggest that regional variation, previously observed in switchgrass production across sites, is partly driven by interactions with local soil microbial communities.

The large role of soil inocula is consistent with a role of microorganisms separate from nutrients and other soil properties. In previous work, Kiniry et al. [4] showed large cultivar by site interactions on switchgrass yield. Here, Temple and Columbia soils ameliorated negative soil feedback compared to Mt. Vernon and Stillwater for all cultivars, which is only consistent with observed Alamo yields in the field [4]. However, in exploring the observed non-significant trend $(P=0.078)$ for the interaction of cultivar by soil inoculum, lowland ecotypes appear to have smaller yield reductions in live soils, particularly Temple and Columbia soils, compared to upland ecotypes. Cultivar effects may also have been limited by growing plants in greenhouse pots, which can constrain plant size. For example, the observed decrease in tiller number was likely due to tiller competition and self-thinning in the pots. Additional field studies are needed to better understand the potential regional variation in cultivar responses to local soil microbial communities.

The dependence of switchgrass growth form on cultivar and soil inoculum source during the growing season was observed for both plant height and tiller number. Unlike final biomass, control soils were not always the most beneficial for growth. Height depended on the interaction of cultivar and soil inoculum source across time, reflecting different height growth trajectories. Tiller number also depended on the interaction of cultivar and soil, but ranks were not the same as for height. A substantial literature has focused on trait spectra for switchgrass cultivars as a function of abiotic conditions [1,31-34], but cultivar-specific trait lability generated by the biotic component of soils may require us to revisit theories of their underlying drivers.

Given the extent of home vs. away effects in the ecological literature, the lack here was surprising. It is possible that we were working at the wrong scale by using regional matches, rather than those from the specific site of origin. Alternatively, it may be that the cultivated nature of switchgrass has divorced this species from the evolutionary processes that lead to the development of local adaptation. This is supported by the lack of relationships between switchgrass climate responses and their climate origins [34], despite extensive latitudinal and longitudinal adaptation [2,3]. The identification of mechanisms of plant-microbial interactions are needed to determine the drivers of switchgrass soil feedback.

The overall reduction in biomass observed with live soil suggests that microbes are at least consuming plant carbon, but likely also reflects the presence of pathogens. In studies where beneficial and pathogenic microorganisms are separately manipulated, they have opposing effects on the outcome of plant-soil feedback [35]. Other aspects of the microbial community that may also be important, such as composition or diversity [36], were not measured here. However, fungal root colonization did not follow patterns of plant-soil feedback or plant biomass and root colonization rates were similar between control and treated soils, suggesting limited fungal influence. Overall root colonization by fungi was low, $<35 \%$ for mycorrhizal hyphae and $<14 \%$ for non-mycorrhizal hyphae, compared to $69-100 \%$ colonization of switchgrass roots in the field [37]. Low fungal abundance may have been caused by soil sieving removing root fragments from the soils used as inocula. As a result, bacteria and viruses may have been more important in this experiment. Switchgrass cultivars, including the four studied here, do vary in both bacteria and fungi that accumulate in their soils [38]. More detailed manipulations are needed to identify the components of these communities that alter plant-soil interactions. Finally, it would be interesting to investigate the generality of these responses in field conditions with less limited rooting environments. 


\section{Conclusions}

The predominant role of soil microbial origin, rather than cultivar, on switchgrass growth suggests that planning for future production may benefit from consideration of soil microbial properties, much like annual cropping systems where management is focused on disease suppression. Plant-soil feedback appears to be consistent at the ecotype level, and not associated with cultivars per se, although additional cultivars should be tested to understand the generality of this observation. Finally, the lack of regional matching between cultivar and soil source, i.e., the lack of home versus away effects, suggests that local adaptation to microbial communities is not a driver of growth or feedback.

Author Contributions: C.V.H. and J.R.K. designed the experiment and wrote the manuscript. C.E.A. and K.M.B. carried out the experiment. C.V.H. analyzed the data. F.B.F. and Y.W. provided soils for inoculation and edited the manuscript. USDA is an equal opportunity provider and employer. All authors have read and agreed to the published version of the manuscript.

Funding: This work was conducted as part of the activities of the USDA Natural Resources Conservation Service Conservation Effects Assessment Project (NRCS-CEAP), Interagency Reimbursable Agreement \#60-3098-5-006. Portions of this work were also supported by USDA Hatch (accession no. 1018688) and DOE Genomic Sciences Program SFA (SCW1039) subaward from Lawrence Livermore National Lab to CVH.

Acknowledgments: The authors thank Rick Greeson and Amber Williams for assistance with greenhouse and lab work.

Conflicts of Interest: The authors declare no conflict of interest.

\section{References}

1. Aspinwall, M.J.; Lowry, D.B.; Taylor, S.H.; Juenger, T.E.; Hawkes, C.V.; Johnson, M.-V.V.; Kiniry, J.R.; Fay, P.A. Genotypic variation in traits linked to climate and aboveground productivity in a widespread C4grass: Evidence for a functional trait syndrome. New Phytol. 2013, 199, 966-980. [CrossRef] [PubMed]

2. Casler, M.D.; Vogel, K.P.; Taliaferro, C.M.; Ehlke, N.J.; Berdahl, J.D.; Brummer, E.C.; Kallenbach, R.L.; West, C.P.; Mitchell, R.B. Latitudinal and Longitudinal Adaptation of Switchgrass Populations. Crop. Sci. 2007, 47, 2249-2260. [CrossRef]

3. Casler, M.D.; Vogel, K.P.; Taliaferro, C.M.; Wynia, R.L. Latitudinal Adaptation of Switchgrass Populations. Crop. Sci. 2004, 44, 293-303. [CrossRef]

4. Kiniry, J.R.; Anderson, L.C.; Johnson, M.-V.V.; Behrman, K.D.; Brakie, M.; Burner, D.; Cordsiemon, R.L.; Fay, P.A.; Fritschi, F.B.; Houx, J.H., III; et al. Perennial Biomass Grasses and the Mason-Dixon Line: Comparative Productivity across Latitudes in the Southern Great Plains. BioEnergy Res. 2012, 6, $276-291$. [CrossRef]

5. Kiniry, J.R.; Johnson, M.-V.V.; Bruckerhoff, S.B.; Kaiser, J.U.; Cordsiemon, R.L.; Harmel, R.D. Clash of the Titans: Comparing Productivity Via Radiation Use Efficiency for Two Grass Giants of the Biofuel Field. BioEnergy Res. 2011, 5, 41-48. [CrossRef]

6. Lowry, D.B.; Behrman, K.D.; Grabowski, P.; Morris, G.P.; Kiniry, J.R.; Juenger, T.E. Adaptations between Ecotypes and along Environmental Gradients in Panicum virgatum. Am. Nat. 2014, 183, 682-692. [CrossRef]

7. Kiniry, J.R.; Sanchez, H.; Greenwade, J.; Seidensticker, E.; Bell, J.R.; Pringle, F.; Peacock, G.; Rives, J. Simulating grass productivity on diverse range sites in Texas. J. Soil Water Conserv. 2002, 57, 144.

8. Kulmatiski, A.; Beard, K.H.; Stevens, J.R.; Cobbold, S.M. Plant-soil feedbacks: A meta-analytical review. Ecol. Lett. 2008, 11, 980-992. [CrossRef]

9. Cortois, R.; Schröder-Georgi, T.; Weigelt, A.; Van Der Putten, W.H.; De Deyn, G.B. Plant-soil feedbacks: Role of plant functional group and plant traits. J. Ecol. 2016, 104, 1608-1617. [CrossRef]

10. Mariotte, P.; Mehrabi, Z.; Bezemer, T.M.; De Deyn, G.B.; Kulmatiski, A.; Drigo, B.; Veen, G.; Van Der Heijden, M.G.; Kardol, P. Plant-Soil Feedback: Bridging Natural and Agricultural Sciences. Trends Ecol. Evol. 2018, 33, 129-142. [CrossRef]

11. Dias, T.; Dukes, A.; Antunes, P.M. Accounting for soil biotic effects on soil health and crop productivity in the design of crop rotations. J. Sci. Food Agric. 2015, 95, 447-454. [CrossRef] [PubMed]

12. Hughes, A.R.; Inouye, B.D.; Johnson, M.T.J.; Underwood, N.; Vellend, M. Ecological consequences of genetic diversity. Ecol. Lett. 2008, 11, 609-623. [CrossRef] [PubMed] 
13. Crawford, K.M.; Hawkes, C.V. Soil precipitation legacies influence intraspecific plant-soil feedback. Ecology 2020, 101, e03142. [CrossRef]

14. Ronsheim, M.L. Plant Genotype Influences Mycorrhiza Benefits and Susceptibility to a Soil Pathogen. Am. Midl. Nat. 2016, 175, 103-112. [CrossRef]

15. Pérez-Izquierdo, L.; Zabal-Aguirre, M.; González-Martínez, S.C.; Buée, M.; Verdú, M.; Rincón, A.; Goberna, M. Plant intraspecific variation modulates nutrient cycling through its below ground rhizospheric microbiome. J. Ecol. 2019, 107, 1594-1605. [CrossRef]

16. Revillini, D.; Gehring, C.A.; Johnson, N.C. The role of locally adapted mycorrhizas and rhizobacteria in plant-soil feedback systems. Funct. Ecol. 2016, 30, 1086-1098. [CrossRef]

17. Van Grunsven, R.H.A.; Van Der Putten, W.H.; Bezemer, T.M.; Tamis, W.L.M.; Berendse, F.; Veenendaal, E.M. Reduced plant? Soil feedback of plant species expanding their range as compared to natives. J. Ecol. 2007, 95, 1050-1057. [CrossRef]

18. Mills, K.E.; Bever, J.D. Maintenance of diversity within plant communtiies: Soil pathogens as agents of negative feedback. Ecology 1998, 79, 1595-1601. [CrossRef]

19. Petermann, J.S.; Fergus, A.J.F.; Turnbull, L.A.; Schmid, B. Janzen-Connell Effects Are Widespread And Strong Enough To Maintain Diversity In Grasslands. Ecology 2008, 89, 2399-2406. [CrossRef]

20. Maron, J.L.; Klironomos, J.; Waller, L.; Callaway, R.M. Invasive plants escape from suppressive soil biota at regional scales. J. Ecol. 2013, 102, 19-27. [CrossRef]

21. Johnson, N.C.; Wilson, G.W.T.; Bowker, M.A.; Wilson, J.A.; Miller, R.M. Resource limitation is a driver of local adaptation in mycorrhizal symbioses. Proc. Natl. Acad. Sci. USA 2010, 107, 2093. [CrossRef] [PubMed]

22. Meisner, A.; Gera Hol, W.H.; de Boer, W.; Krumins, J.A.; Wardle, D.A.; van der Putten, W.H. Plant-soil feedbacks of exotic plant species across life forms: A meta-analysis. Biol. Invasions 2014, 16, 2551-2561. [CrossRef]

23. Porter, C.L., Jr. An analysis of variation between upland and lowland switchgrass, Panicum virgatum L., in central Oklahoma. Ecology 1966, 47, 980-992. [CrossRef]

24. Brunken, J.N.; Estes, J.R. Cytological and morphological variation in Panicum virgatum L. Southwest. Nat. 1975, 19, 379-385. [CrossRef]

25. Stroup, J.A.; Sanderson, M.A.; Muir, J.P.; McFarland, M.J.; Reed, R.L. Comparison of growth and performance in upland and lowland switchgrass types to water and nitrogen stress. Bioresour. Technol. 2003, 86, 65-72. [CrossRef]

26. Aurangzaib, M.; Moore, K.J.; Archontoulis, S.V.; Heaton, E.A.; Lenssen, A.W.; Fei, S. Compositional differences among upland and lowland switchgrass ecotypes grown as a bioenergy feedstock crop. Biomass Bioenergy 2016, 87, 169-177. [CrossRef]

27. Hawkes, C.V.; Kivlin, S.N.; Du, J.; Eviner, V.T. The temporal development and additivity of plant-soil feedback in perennial grasses. Plant Soil 2013, 369, 141-150. [CrossRef]

28. Merryweather, J.W.; Fitter, A.H. A modified method for elucidating the structure of the fungal partner in a vesicular-arbuscular mycorrhiza. Mycol. Res. 1991, 95, 1435-1437. [CrossRef]

29. McGonigle, T.P.; Miller, M.H.; Evans, D.G.; Fairchild, G.L.; Swan, J.A. A new method which gives an objective measure of colonization of roots by vesicular-Arbuscular mycorrhizal fungi. New Phytol. 1990, 115, 495-501. [CrossRef]

30. Pernilla Brinkman, E.; Van der Putten, W.H.; Bakker, E.-J.; Verhoeven, K.J.F. Plant-soil feedback: Experimental approaches, statistical analyses and ecological interpretations. J. Ecol. 2010, 98, 1063-1073. [CrossRef]

31. Hopkins, A.A.; Vogel, K.P.; Moore, K.J.; Johnson, K.D.; Carlson, I.T. Genotypic Variability and Genotype $\times$ Environment Interactions among Switchgrass Accessions from the Midwestern USA. Crop. Sci. 1995, 35, 565-571. [CrossRef]

32. Cassida, K.A.; Muir, J.P.; Hussey, M.; Read, J.; Venuto, B.; Ocumpaugh, W. Biomass Yield and Stand Characteristics of Switchgrass in South Central U.S. Environments. Crop. Sci. 2005, 45, 673-681. [CrossRef]

33. Liu, Y.; Zhang, X.; Tran, H.; Shan, L.; Kim, J.; Childs, K.L.; Ervin, E.H.; Frazier, T.P.; Zhao, B. Assessment of drought tolerance of 49 switchgrass (Panicum virgatum) genotypes using physiological and morphological parameters. Biotechnol. Biofuels 2015, 8, 1-18. [CrossRef] [PubMed]

34. Aspinwall, M.J.; Fay, P.A.; Hawkes, C.V.; Lowry, D.B.; Khasanova, A.; Bonnette, J.; Whitaker, B.K.; Johnson, N.; Juenger, T.E. Intraspecific variation in precipitation responses of a widespread C4grass depends on site water limitation. J. Plant Ecol. 2016, 10, 310-321. [CrossRef] 
35. Klironomos, J.N. Feedback with soil biota contributes to plant rarity and invasiveness in communities. Nat. Cell Biol. 2002, 417, 67-70. [CrossRef]

36. Semchenko, M.; Leff, J.W.; Lozano, Y.M.; Saar, S.; Davison, J.; Wilkinson, A.; Jackson, B.G.; Pritchard, W.J.; De Long, J.R.; Oakley, S.; et al. Fungal diversity regulates plant-soil feedbacks in temperate grassland. Sci. Adv. 2018, 4, eaau4578. [CrossRef]

37. Emery, S.M.; Kinnetz, E.R.; Bell-Dereske, L.; Stahlheber, K.A.; Gross, K.L.; Pennington, D. Low variation in arbuscular mycorrhizal fungal associations and effects on biomass among switchgrass cultivars. Biomass Bioenergy 2018, 119, 503-508. [CrossRef]

38. Ulbrich, T.C.; Friesen, M.L.; Roley, S.S.; Tiemann, L.K.; E Evans, S. Intraspecific variability in root traits and edaphic conditions influence soil microbiomes across 12 switchgrass cultivars. Phytobiomes J. 2020. [CrossRef]

Publisher's Note: MDPI stays neutral with regard to jurisdictional claims in published maps and institutional affiliations.

(C) 2020 by the authors. Licensee MDPI, Basel, Switzerland. This article is an open access article distributed under the terms and conditions of the Creative Commons Attribution (CC BY) license (http://creativecommons.org/licenses/by/4.0/). 